\title{
Disputed Past: The Friendship and Competing Memories of Anna Lesznai and Emma Ritoók
}

\section{Judith Szapor, McGill University}

Abstract: This paper is part of a larger research project that explores the contributions of women intellectuals to the nationalistic, anti-liberal rhetoric of the early 1920s and the gendered aspect of the official ideology of the Horthy-era. The paper probes the connection of the personal and the political by exploring the shared history and competing memories of two woman writers, Anna Lesznai (1885-1966) and Emma Ritoók (1868-1945). The writers were friends and founding members of the Sunday Circle in 1915 but ended up in opposite camps during the 1918-19 revolutions. Ritoók, with Cécile Tormay, became a champion of the counter-revolution, contributing to its anti-Semitic ideology and rhetoric. Lesznai, the wife of Oszkár Jászi and a supporter of the Republic of Councils, was forced to flee and she spent the rest of her life in exile. Their diaries and autobiographical novels reflect the two writers' diagonally opposing perspectives on their past and their shared intellectual and spiritual home, the Sunday Circle. The juxtaposition of their respective biographies and literary works offers insight into the process of re-interpreting and re-writing the past, whether for personal or political ends. It also illustrates the broader contours and irreparable breach between the Left and the nationalistic Right in Hungarian political and intellectual life after 1919.

Keywords: Revolutions of 1918-1919, counter-revolution, Sunday Circle, Horthy-era, anti-Semitism, right-wing women

Biography: Judith Szapor is Assistant Professor at the Department of History and Classical Studies of McGill University in Montreal, Canada. She teaches courses on EastCentral Europe, the social and cultural history of Austria-Hungary, European women in the modern era, and the history of the intellectual refugees. Her current research on Hungarian right-wing woman politicians in the interwar period is supported by a Social Sciences and Humanities Research Council of Canada Standard Research Grant. 


\section{Introduction: A Horthy and Tormay Renaissance}

At the writing of this article, there are unmistakable signs that a fundamental reassessment of the Horthy-era and Horthy himself is underway in Hungary. After many decades of being condemned as an authoritarian leader who was largely responsible for the White Terror after 1919 and was a willing ally of Nazi Germany, Horthy is staging a comeback. The statues, plaques and street names recently dedicated to Hungary's head of state between 1920 and 1944 may be explained away as the expression of the popular will by local citizens - after all, the renaming of streets has been a favorite parlor game of Hungarians for the last hundred years. But these activities are now given official seal of approval by the presence of government representatives and seem to fit into what is emerging as coherent government policy - in the words of one foreign journalist, a "veritable populist-nationalistic renaissance" (Verseck 2012, 1). The Hungarian government's announcement of the restoration of Kossuth Square around Parliament to its pre-1944 state (with the prompt removal of the statue of Mihály Károlyi as its first step), as well as the designation (sanctioned by a bill introduced in June 2010) of June $4^{\text {th }}$, the date of the signing of the Trianon Treaty as the Day of National Solidarity are but two examples of this policy.

The emerging cult of Horthy is particularly striking when manifested in cultural policies and practices. In 2001, and again in 2010, the FIDESz government re-instated the Corvin-chain, the highest civilian decoration of the 1930s, awarded to such pillars of the interwar conservative establishment as Pál Teleki, Kunó Klebelsberg, Bálint Hóman, and Ferenc Herczeg. In June 2012 the Hungarian government introduced a new national curriculum that, despite the protests of the Association of Teachers of Hungarian Language and Literature, made the works of József Nyirö and Albert Wass, writers of dubious literary merit but toxic anti-Semitic views, mandatory readings (Magyar Közlöny 2012, http://www.magyartanarok.freeweb.hu/frames.html). The popular novels of Nyirö and Wass had been banned after 1945; their recently re-printed works are bestsellers today.

Following on the heels of Wass and Nyirö is Cécile Tormay, although her works have yet to make it into the national curriculum. Tormay was president of the right-wing National Association of Hungarian Women (MANSz), and one of the staunchest supporters of the counter-revolution. Her fictional diary, An Outlaw's Diary (Bujdosó könyv, vol. 1, 1920, vol. 2, 1921, English and French editions 1923 and 1925, respectively), purportedly written during the revolutions, is a noxiously anti-Semitic work. In 2009 Judit Kádár already commented on the rise of Tormay's currency and the shift of her appeal - as a writer and public figure - from the extreme right to the mainstream. Unlike previous editions, which were sold on the street by extreme-right booksellers, copies of the 2009 edition of Tormay's anti-Semitic An Outlaw's Diary are widely available in mainstream bookstores and branches of the Budapest Public Library (Kádár 2009 , 3). Further signs that Tormay's rehabilitation is under way are the first monograph written about her, by Krisztina Kollarits (2010), and the unveiling of her bust in front of Rókus Hospital, a central spot in Budapest. Kollarits' book displays all the formal requisites of a scholarly work but it is in fact a highly partisan contribution to the rightwing campaign launched to rescue Tormay's literary and political legacy. 
Szapor, Judith. "Disputed Past: The Friendship and Competing Memories of Anna Lesznai and Emma Ritoók." AHEA: E-journal of the American Hungarian Educators Association, Volume 5 (2012):

http://ahea.net/e-journal/volume-5-2012

Signs of a Horthy cult in the making even stirred debates among academics, usually reluctant to engage with daily politics. The recent Gerö-Romsics debate had been, to a great degree, sparked by the emerging cult of Horthy. As the debate is still ongoing, and at the writing of this article, in August 2012, might even be picking up steam, it is much too early to summarize its course and results. The debacle was provoked by the article of the historian András Gerő in which he accused Ignác Romsics, the leading conservative historian of the Horthy era, of anti-Semitism (Gerö 2012) and questioned Romsics' moderately positive assessment of the Horthy era. So far, rather than clarifying the issues at stake and addressing the general public, the debate has been mainly characterized by personal attacks, the settling of personal scores, and the re-trenchement of alliances within the historical profession. In other words, it has so far failed to develop into a Hungarian Historikerstreit and has accomplished little in terms of influencing popular - and populist - historical perceptions (for more on this debate see Gerö, Romsics 2102, Bojtár 2012, and Pók 2012; see also the online editions of Rubicon, Élet és Irodalom, and Galamus).

This article is part of a broader research project that aims to contribute to a better understanding of the early years of the Horthy regime. My project has been shaped by previous research interests and, originally, had been only marginally influenced by recent Hungarian political trends. However, the political developments in Hungary described above have highlighted the need for research, such as mine, that addresses the origins and development of right-wing social and intellectual strands in Hungarian society. While recent scholarly interest in the history of the Hungarian Right has produced valuable studies on the political and intellectual history of the Horthy-period, my research probes aspects that have been largely ignored by this scholarship, such as the contributions of right-wing women politicians to the nationalistic, anti-liberal rhetoric of the early 1920s, the gendered nature of the official ideology of the Horthy era, and the reasons for its popular appeal, especially among women. It is remarkable that such a venerated public figure of the interwar period as Cécile Tormay has not been the subject of any serious scholarly study. In a recent, representative volume of articles on the Hungarian conservative tradition, edited by the period's leading historian, Ignác Romsics, her name figures, in passing, on only three of the volume's 576 pages (Romsics 2009). In the absence of any preexisting critical studies on Tormay as a writer and public figure, her current champions are given free reign to shape public opinion on their own terms. By the same token, if Hungarian historians today fail to address the official rehabilitation of the Horthy era more forcefully, they will allow the political Right and the extreme Right to determine the legacy of a crucial period of Hungary's history.

The ongoing re-assessment of the interwar period should command the interest of historians all the more because it seems to echo an earlier attempt by Hungarian politicians and intellectuals, in the wake of the failed revolutions of 1918-19, to set government agenda by re-evaluating the preceding political period. Tormay's $A n$ Outlaw's Diary and other programmatic works - whether literary or scholarly, such as Dezső Szabó's Az elsodort falu (Swept-away Village, 1919) or the historian Gyula Szekfü's Három nemzedék (Three Generations, 1920) - were all grounded in a radical reinterpretation of Hungary's then recent history. While all three authors advanced an antiliberal agenda, it was Tormay's book, with its visceral anti-Semitism and exclusive focus 
Szapor, Judith. "Disputed Past: The Friendship and Competing Memories of Anna Lesznai and Emma Ritoók." AHEA: E-journal of the American Hungarian Educators Association, Volume 5 (2012): http://ahea.net/e-journal/volume-5-2012

on the revolutions of 1918 and 1919, that provided the most resounding articulation of the foundational myth of the Horthy-period: that Hungary's defeat and the disaster of Trianon was the result of the conspiracy of Jews, liberals, and the political and intellectual Left.

Tormay was the most prominent but by no means the only important representative of a new breed of female public intellectuals who contributed to the counter-revolutionary agenda of the interwar period. One of them was Emma Ritoók, Tormay's fellow writer, activist, and sister-in-law. Ritoók, with Tormay, was among the organizers of MANSz, the National Organization of Hungarian Women that began as a clandestine, counter-revolutionary gathering under the Károlyi-government and during the 1920s became the largest women's movement, with a right-wing, pro-government agenda. Although the two worked closely together until the fall of the revolutions, they had a falling-out once the counter-revolution triumphed, with Ritoók feeling sidelined by Tormay who, she claimed, had dropped her in favor of better-connected friends.

If Ritoók's adjustment to the new political and intellectual scene proved more conflicted than Tormay's, it is in part because Ritoók arrived there through a more circuitous route. Tormay may have cultivated ties to liberal literary circles before 1918 but her political and literary tastes were always firmly grounded in the Hungarian nationalist and conservative tradition, and she had become a bestselling novelist and the darling of aristocratic salons before the war. In contrast, Ritoók as a writer aspired to be accepted into the Nyugat (West), the period's leading avant-garde literary forum, before finding her intellectual home among the writers and philosophers of the Sunday Circle, the most important workshop of Hungarian philosophy of the pre-war period and an institution of the progressive counter-culture in fin-de-siècle Hungary.

Ritoók's memoirs and literary works after 1918 betray an intense, almost obsessive preoccupation with her past and the need to justify the radical shift in her personal and literary associations from the liberal to the conservative camp. Central to this preoccupation is an ongoing reflection on her relationship with members of the Sunday Circle before 1918. Here I will discuss Ritoók's relationship with fellow writer and Sunday Circle member Anna Lesznai. Although they were not particularly close both developed more significant friendships with Béla Balázs and Lukács, and, in Ritoók's case, with Béla Zalai - their respective life course and works offer enlightening parallels and differences as well as more than the occasional reflections of one another.

\section{Emma Ritoók and Anna Lesznai: The history of a friendship}

In early 1918 the Countess Katinka Andrássy, wife of Count Mihály Károlyi, leader of the opposition Independence and 1848 Party, opened her home, the Károlyis' palace in downtown Budapest, to the meetings of the "Women's Club." The Club was Katinka's brainchild, modeled on the English gentlemen's clubs and meant to encourage women's participation in politics (Károlyiné 1967, 249-51). Károlyi and his wife had been long-time supporters of female suffrage and friends of Rózsa Schwimmer, the leader of the liberal feminists. In October 1918 the Austro-Hungarian Monarchy ceased to exist, and two weeks later Hungary became a republic, with Károlyi as its first President. His support of women's rights was reflected in the first decree of the 
Szapor, Judith. "Disputed Past: The Friendship and Competing Memories of Anna Lesznai and Emma Ritoók." AHEA: E-journal of the American Hungarian Educators Association, Volume 5 (2012): http://ahea.net/e-journal/volume-5-2012

governing National Council in November 1918 that introduced universal suffrage, including that of women.

From then on Katinka's efforts in the Club focused on drumming up support for the Károlyi-government among her aristocratic friends and relatives, enticing them to explore the newly opened space for women in political life, and keeping them in the same room with the liberal feminists. The Club proved to be a failure on all these counts and ended up as yet another gathering that reflected the growing division between the democratic left and the nationalist right. Soon enough, the aristocratic ladies, related to or invited by Katinka, began plotting against the democratic republic right under her eyes. The writer Emma Ritoók described the Club's meeting in December 1918 in her memoirs:

Despite my expectations there are a great many people at the meeting, from the party of Mrs. Károlyi [and] many Jewish women who until now had not participated in the activities of the Club - I've known them as Radicals - the Polányis, Mrs. Jászi whom I saw for the last time there (...), many feminists; Mrs. Károlyi showed off her entire regiment... Only Mrs. Jászi noticed me: "I see you are with the countesses now," she said somewhat sarcastically. "With the good Hungarians," I replied and I felt (...) a range of emotions running through me, regret, stupidity, bitterness, betrayal, that I had spent so much time with these people." [Várakozásom ellenére nagyon sokan vannak a gyülésen még pedig a Károlyiné pártjából. Sok zsidó asszony, akik eddig nem vettek részt a klub életében - radikális hirükből ismerem őket - Polányiék, Jásziné, akivel ekkor találkoztam utoljára (... ) és sok feminista; Károlyiné az egész seregével kirukkolt. (...) Csak Jásziné szólitott meg: - Úgy látszik, most a grófnékkal vagy együtt, - mondta kissé gúnyosan. - A jó magyarokkal, - feleltem és éreztem, hogy egy pillanatra minden végigszalad bennem, mint megbánás, ostobaság, mint keserüség, megcsalatás, hogy ezekkel az emberekkel annyit voltam együtt.] (Ritoók 1914-33, 292-93) ${ }^{1}$

The Mrs. Jászi mentioned here is no other than Anna Lesznai, and the fleeting reference to their last meeting belies the long history of Ritoók's and Lesznai's friendship. Their acquaintance began around 1910 and their friendship would be further cemented in the sessions of the Sunday Circle from 1915. Both Ritoók and Lesznai were among the founding members of the informal Sunday gatherings, held at the apartment of the poet Béla Balázs and presided over by György Lukács. But by 1918 Ritoók’s path took a sharp turn to the Right while Balázs, Lukács, and others in the circle had begun their journey to messianistic Communism. Early 1919 found them on opposing sides of the barricades, Ritoók among the plotters of the counter-revolution, Lukács and some of her

\footnotetext{
1 All translations from Hungarian sources and all ellipses are mine. My translation of the excerpts from Ritoók's memoirs reflects its occasionally fractured style. The "Radicals" in the quotation refer to members of the Bourgeois Radical Party, led by Oszkár Jászi; the Polányis mentioned are Cecile Pollacsek and Laura Polányi.
} 
Szapor, Judith. "Disputed Past: The Friendship and Competing Memories of Anna Lesznai and Emma Ritoók." AHEA: E-journal of the American Hungarian Educators Association, Volume 5 (2012): http://ahea.net/e-journal/volume-5-2012

erstwhile friends in the leadership of the Hungarian Republic of Councils. While not all former Sunday members became Communists or wholehearted supporters of the Hungarian Commune, Ritoók was the only one who ended up on the side of the counterrevolution.

The December 1918 encounter between Ritoók and Lesznai thus had a significance that went well beyond the personal: it did not merely signal the end of a friendship but rather a point of no return that applied to the entire Hungarian political and intellectual scene. The paths of Hungarian nationalism and social-political progress had diverged since the early years of the century and the divisions further deepened during the 1906 political crisis and the war years. While the Károlyi revolution temporarily restored a broad coalition of Hungarian liberal nationalists, socialists, and bourgeois radicals, the government's democratic reforms and its unsuccessful efforts to preserve Hungary's territorial integrity quickly eroded this alliance and led to a break during the Republic of Councils in March 1919, and, finally, the triumphant counter-revolution in August 1919. The history and irreversible end of the two women's friendship thus reflected the broader contours of Hungarian political and intellectual life, with the entrenchment of the opposing sides of Left and Right, and the embrace or rejection of Western liberalism and socialism or nationalism. The respective diaries of Lesznai and Ritoók provide insight into the broader political divisions experienced on the level of a personal relationship. Complemented with their autobiographical novels, Lesznai's Kezdetben volt a kert (In the Beginning Was the Garden, 1966) and Ritoók's A szellem kalandorai (The Adventurers of the Spirit, 1921) they created highly conflicting narratives of their shared past and reflected on the broader implications of their diverging paths. The existence of such parallel diaries and romans à clef, written by two women writers with roots in a shared intellectual milieu and ending up in opposing political camps, provides a rare opportunity to observe the articulation of competing memories. Finally, the exploration of this process and the works themselves contributes to ongoing debates about the legacy of the two writers and their place - or absence - in the Hungarian literary canon.

\section{Biographies and transgressions}

The friendship between Emma Ritoók (1868-1945) and Anna Lesznai (18851966) was an unlikely one under the best of circumstances. By their social origins, upbringing, and temperament, the two women were worlds apart. András Lengyel's excellent study of Ritoók describes her roots in Nagyvárad's old-stock gentry, Calvinist, moderately modernizing milieu (Lengyel 1994, 10-11) into which Ritoók was born in 1868. Her father was a highly respected judge who contributed articles to the local press on questions of philosophy and social sciences and encouraged his daughter to read. (Lengyel 1994, 11) However, Ritoók had a fairly conventional upbringing, and as she was not judged to be attractive enough to marry, she seemed condemned to a life of spinsterhood. But against all expectations, in 1900 at age 32 she enrolled at the University of Budapest, and spent subsequent semesters in Leipzig, Berlin, and Paris. There she studied philosophy, literature, and psychology, and befriended members of the future Nyugat generation such as Gyula Juhász and Mihály Babits, as well as future Sunday Circle members Béla Zalai and Béla Balázs. She also published two well- 
Szapor, Judith. "Disputed Past: The Friendship and Competing Memories of Anna Lesznai and Emma Ritoók." AHEA: E-journal of the American Hungarian Educators Association, Volume 5 (2012): http://ahea.net/e-journal/volume-5-2012

received novels, Egyenes úton egyedül (On a Straight Path, Alone 1903) and A nagy véletlen (The Great Coincidence 1907) and in 1906 graduated with a doctorate in Hungarian literature.

Lesznai was born Amália Moscovitz (she took the pen name Anna Lesznai but was called Máli by her friends) half a generation later, in 1885. Her mother, a member of the Hatvany Deutsch clan, one of the leading ennobled Jewish industrialist families of Hungary, was the cousin of Lajos Hatvany, writer, supporter of the arts, and one of the founders of the avant-garde literary journal Nyugat (The West). Lesznai's father, Geyza Moscovitz, was the son of Mór Moscovitz, physician to the Andrássy family. Geyza Moscovitz was well known for his gentry lifestyle and the abandon with which he spent most of his wife's wealth. During the summer, the family's estate at Körtvélyes in Northern Hungary would receive a steady stream of visitors from the political and intellectual elite. In the winter, Moscovitz would hold a permanent open house, colloquially named "jungli" after Kipling, at his Budapest home. Oszkár Jászi depicted it in his memoirs as a place where liberal politicians and rebels of all shades mingled, symbolizing the tolerance of pre-war liberalism (Jászi 1955, 557-58).

Lesznai chronicled her freewheeling upbringing in this wealthy and eccentric family in her autobiographical novel, Kezdetben volt a kert. Apart from art training in Budapest and Paris, she received no formal education but experienced early success. Her poems appeared in the Nyugat and in 1909 in a collection of poetry, and she exhibited her folklore-inspired paintings and embroideries, both with the modernist group the Eight and independently. Her artistic endeavors as well her transgressions, such as her divorce from her first husband, single motherhood, and rather public love affairs, were eased by her family's wealth, making her bohemian lifestyle comfortable. Her privileged financial circumstances were forgiven by her genuinely bohemian artist friends, who were the beneficiaries not only of her occasional financial support, but also of her warmth and generosity.

Unlike Lesznai, Ritoók never married. Apart from her rumored, unrequited love for the German philosopher Ernst Bloch and a possible, fleeting affair with Balázs, she lived the life of a single woman. Her comfortable but by no means extravagant circumstances changed when her father died in 1905, without leaving any substantial income to his daughters. While Ritoók's brother, Zsigmond, became a successful physician and likely supported his sisters, from then on money matters figured prominently in Ritoók's memoirs, with frequent, bitter remarks directed against anyone living more comfortably.

Neither Lesznai nor Ritoók were typical products of their milieu or typical in any way. Both of them bridged worlds; Lesznai had a foot in at least four, the first two through her family's estate in Northern Hungary, where she was a part of her father's gentry world but also keenly interested in the rural universe of the Slovak peasants of the estate. She was equally at home in the rarified, urban milieu of the Sunday Circle, and was especially close to Balázs and Lukács. Lesznai personified and kept up, perhaps more than any other member of the circle, the "Sunday" spirit with its unique intellectual and philosophical mix. The graphic artist Tibor Gergely, her third and last husband and companion from 1920 until her death, was also a member. During their shared exile in Vienna and, after 1938, the U.S. they made valiant efforts to revive the Sunday Circle. 
Szapor, Judith. "Disputed Past: The Friendship and Competing Memories of Anna Lesznai and Emma Ritoók." AHEA: E-journal of the American Hungarian Educators Association, Volume 5 (2012):

http://ahea.net/e-journal/volume-5-2012

Last, Lesznai was also accepted into Jászi’s circle, that of the social scientists of the journal Twentieth Century. She seemed unconcerned with social conventions of any kind, let alone those of her upper-class milieu. For example, she had no difficulty in accepting the notorious promiscuity of Balázs, her closest friend in the Sunday Circle, who lived in a ménage-à-trois.

If in less spectacular ways, Ritoók also straddled worlds. She exchanged her traditional, Protestant surroundings for the bohemian world of students in Berlin and Paris, a choice most unusual for a woman in her 30s. Then, close to 40, she decided to make it as an independent writer and intellectual. Ritoók's drive to transgress the boundaries prescribed for a middle-aged, single, upper-middle-class woman was rooted in her literary and intellectual ambitions but limited by financial considerations. From 1912 on Ritoók lived in Mátyásföld, a suburb of Budapest, in a villa of her own design but, as she complained in her memoirs, at an inconvenient distance from the city's elegant central districts. Her household consisted of her unmarried sister and their niece, their younger brother's daughter, whom they raised as their own. For all her intellectual trailblazing, Ritoók relapsed into a patriarchal pattern in her relationship with her brother, Zsigmond, who became the head of the family after their father's death, with the sisters acquiescing to his decisions in important family matters. Zsigmond married Cécile Tormay's younger sister, thereby creating the family connection between Ritoók and her friend, the future leader of MANSz. Well-known for his deep anti-Semitic convictions, Zsigmond also must have had an influence on Ritoók's disavowal of her "Sunday" friends and turn to the political Right.

This is not the place to recount in detail the rest of the Ritoók and Lesznai's lives, but the following main outlines should suffice to illustrate their wildly diverging paths. Ritoók, with Cécile Tormay, was among the founders of MANsz, the National Association of Hungarian Women in January 1919. They were also prominent in the group of right-wing women who conspired and spurred on the counter-revolution, using among other methods the gatherings of Katinka Andrássy (mentioned in the introduction) to conspire against the Károlyi-government. In her memoirs, Ritoók describes her own contribution as substantial to the counter-revolutionary ideology of the early years of the Horthy era, and her sense of betrayal when Tormay took all the credit. Their highly competitive and ambivalent friendship diminished in reverse correlation with Tormay's rise to prominence in the right-wing establishment. By the mid-1920s, Tormay would occupy a highly public role not only as the leader of MANSz, but also as a celebrated political orator, successful writer, and editor of the journal Napkelet (Dawn), which was founded as the right-wing counterweight to Nyugat in 1923. Ritoók watched from the sidelines, lamenting her own inability to bring her literary projects to fruition, and commenting bitterly on her friend's rise while she herself was eking out a meager living as a librarian at the University Library and as a translator of Scandinavian literature. Ritoók's own frustrated plans to start a literary journal and her bitterness over the success of Tormay's Napkelet (whose idea, she claimed, had been hers) led her to open a literary salon that she kept throughout the 1930s. The assortment of young and older writers gathering in her Budapest apartment, which included some of the finest literary talents, would certainly not have withstood the scrutiny of the strict anti-Semitic guidelines she had so strenuously proposed in defense of pure Hungarian, Christian talent in the early 
Szapor, Judith. "Disputed Past: The Friendship and Competing Memories of Anna Lesznai and Emma Ritoók." AHEA: E-journal of the American Hungarian Educators Association, Volume 5 (2012):

http://ahea.net/e-journal/volume-5-2012

days of the Horthy era. Ritoók died in January 1945, without having received much literary recognition.

Lesznai's life after the revolutions was more tumultuous. At the time she was still married, if only in name, to Oszkár Jászi, Minister of Nationalities Affairs in the Károlyi government. While Jászi, opposed to the Communist government, left for Vienna in May 1919, Lesznai, like most of her Sunday friends, supported the Republic of Councils and took up a position at the Ministry of Culture where she was assigned to develop a new art curriculum. After the fall of the Republic of Councils Lesznai escaped Hungary, fearing retribution in her own right as well as in her husband's, who was one of the most hated targets of the counter-revolutionaries. With her soon-to-be third husband, Tibor Gergely, Lesznai found temporary haven in Vienna. A few years later they settled at Lesznai's Körtvélyes estate, which by then was Hrusov, part of the new Czechoslovakia. (As a result of the Czechoslovak land reform, Lesznai was able to keep the family home but lost the surrounding lands.) Continuing the family tradition, her home was always open to artists and writers, and regardless of her much diminished means, she was always ready to support her fellow artists. Lesznai returned to Budapest in 1931 but after the Munich Agreement in 1938 and the resulting dismemberment of Czechoslovakia in 1939 she left Europe and settled in the United States. Until her death in 1966 she lived in New York, surrounded by her beloved folk art and the mementoes of her Körtvélyes garden.

For all their differences, Ritoók and Lesznai had many important similarities; they both belonged to the small group of woman pioneers in the literary world, and as such they might have been natural allies in what was still very much a men's world. But one looks in vain for a single expression of trailblazer's solidarity towards each other in their respective diaries, memoirs, or novels.

The sources explored here are all confessional in nature but represent a range of genres. Ritoók's unpublished memoirs were written after the events they describe, in several installments between 1920 and the early 1940s, while Lesznai's diaries were jotted down between 1912 and 1945, in real time, so to speak. Nevertheless, paradoxically it is Ritoók's memoir entries that are much more firmly rooted in her times, providing close descriptions of events and people, while Lesznai's genuine diaries, kept between 1912 and 1945 (Török 2007, 48) are frustrating reading for the historian as they reveal very little about the "outside life" of its writer. While Ritook kept revising her memoirs throughout the 1920s and early 1930s, clearly with posterity in her sight, Lesznai's diaries were not meant for publication (Török 2007, 50). As for the two autobiographical novels, Ritook's The Adventurers of the Spirit and Lesznai's In the Beginning was the Garden may belong to the roman à clef genre but, as Csilla Markója $(2007,83)$ remarks in her study of three woman writers, Ritoók, Kaffka, and Lesznai, they provide the key to very little. This is not the place to explore the novels of Ritoók and Lesznai - and in any case, their exploration would reap little in terms of references to the other. Both novels feature a thinly disguised, autobiographical female protagonist, placed in the social and intellectual circles of the pre-war era that included the Sunday Circle. In fact, in Ritoók's case it is the Sunday Circle that is the main focus of the novel. But while both writers created other strong female characters in addition to the female protagonist, they each erased the other from their respective, fictionalized account. Neither Ritoók nor Lesznai created a fictional equivalent, not even a remotely identifiable 
Szapor, Judith. "Disputed Past: The Friendship and Competing Memories of Anna Lesznai and Emma Ritoók." AHEA: E-journal of the American Hungarian Educators Association, Volume 5 (2012):

http://ahea.net/e-journal/volume-5-2012

character drawn on the other. This dynamic is addressed in the excellent article by Csilla Markója (2007).

More instructive than the novels for the purposes of this study is the exploration of the respective memoirs of Ritoók and Lesznai. How do they present the other within the context of the Sunday Circle? Lesznai's most factual recollection of the Circle comes from a 1965 interview:

It was very interesting. We gathered at the home of Béla Balázs, the villa on Sun-hill, where I used to go for years. The founders were György Lukács, Balázs and his two wives, Edit Hajós and Anna Schlamadiger. They initiated it and Lukács was its main man. Other founding members were Károly Mannheim, Lajos Fülep, Arnold Hauser, Béla Fogarasi, Ernő Lorsy. These were the old ones. At one point Emma Ritoók used to come as well." [Nagyon érdekes volt. Balázs Béla otthonában, a naphegyi villában gyültünk össze. Alapitói voltak Lukács György, Balázs és a két felesége, Edit Hajós és Schlamadinger Anna. Ök kezdeményezték, és Lukács volt a fỏ embere. Alapitó tagjai még Mannheim Károly, Fülep Lajos, Hauser Arnold, Fogarasi Béla, Lorsy Ernő. Ezek voltak az öregek. Egy időben Ritoók Emma is odajárt.] (Karádi and Vezér 1980, 54)

In light of what we know of the history of the Sunday meetings, pieced together from the recollections of former members, such a narrative was an obvious slight of Ritoók's important contribution. Even more strikingly, in Ritoók's account of the Sunday Circle in her memoirs, Lesznai did not appear at all. On the many hundreds of pages of the memoirs the Sunday Circle was featured in three generous passages, the first concerning its founding in which, according to her own account, Ritoók played an instrumental role. (Ritoók 1914-33, 109) While this fact is well documented, Ritoók's self-appointed role as the circle's intellectual leader - she wrote: "[a]s far as social and ethical questions were concerned, I nearly almost had the final word" [társadalmi és ethikai kérdésekben pedig szinte döntő szavam volt közöttük] (109-110) - is largely unconfirmed by other testimonies. What was at work here was not only Ritoók's characteristic tendency to overstate her own contribution but also her effort to diminish that of Lukács. Perhaps even more interesting is Ritoók's comment on the exceptional inclusiveness extended to women in the Sunday Circle, albeit with an anti-Semitic twist. "These Jewish boys," she noted, "if they were home, did not lose me from their sight; we often debated philosophical and aesthetic questions and, unlike most Christian men, they never exhibited the condescension of male thinkers towards the woman" [Ezek a zsidó fiuk azonban, ha itthon voltak, nem veszitettek el szem elöl, sokat vitatkoztunk filozófiai és művészeti kérdésekről és soha nem éreztették a férfi gondolkozók lenézését a nő iránt - mint a legtöbb keresztyén férfi] (110).

Curiously, unlike Ritoók in the foregoing quote, the place of women in the Circle was an aspect Lesznai never addressed, likely because it was no different from what she had experienced in her own social and family surroundings. (Mary Gluck is the only historian who has raised the issue of gender inclusiveness and the role of women in the Sunday Circle, if only in passing. Gluck 1985, 37-42). To Ritoók, in contrast to Lesznai, 
Szapor, Judith. "Disputed Past: The Friendship and Competing Memories of Anna Lesznai and Emma Ritoók." AHEA: E-journal of the American Hungarian Educators Association, Volume 5 (2012): http://ahea.net/e-journal/volume-5-2012

the inclusiveness of the Sunday Circle towards women represented a fundamental shift from her much more conventional social and family milieu. It was, in a way, the tragedy of her life as an intellectual: the inability to reconcile her intellectual home (the urban, mostly Jewish intellectuals and artists of the Sunday Circle) and her increasingly conservative and anti-Semitic Hungarian upper-middle class family background to which she reverted in the end.

The second instance in Ritoók's memoirs referring to the Sunday meetings reached back to the early days, in 1915, but her narrative of the events from 1920 was already marked by the anti-Semitism that increasingly came to permeate her memoirs. She had invited along a Swedish woman journalist, who was visiting wartime Budapest. The journalist reportedly asked her: "Are there only Jews here one can talk to?" To this question Ritoók replied: "Those that are not Jews, are serving at the front." [...csak zsidók vannak itt, akikkel beszélni lehet? - Nem, hanem akik nem zsidók, azok kint vannak a fronton ] (Ritoók 122). Whether real or invented, the writer's repartee, written down around 1920, was particularly unjust in light of Balázs's front service and the heroic death of Lesznai's brother. It also rehashed the anti-Semitic trope of the supposed shirking of front service by Jews, a charge increasingly prevalent by the latter years of the war. (Bihari 2008, 201-15)

The final entry in Ritoók 's diary concerning the Sunday Circle related the last meeting she attended in November of 1918, a visit prompted by her hope to find comfort, and to jolt her out of her dark mood. Her hope quickly turned into disappointment as she realized that she found herself among the "chief spiritual leaders of the [Károlyi] revolution who had participated in its preparation at the Astoria" [fö szellemi vezetök részt vettek az Astoriában az előkészitésben] (the headquarters of the National Council) (Ritoók 224a). She concluded with yet another of her trademark anti-Semitic rants:

Besides, they all seemed to sense that it will be their turn, their rule (...); it was not yet obvious but there was something different in their tone, a kind of certainty that filled me with uneasy stirrings; I realized that, with few exceptions, I was surrounded by Jews. (...) These strange, placid, in many ways degenerate and different, foreign - a hundred times foreign - people, set against our peasants, our middle class, our entire social life, state and internal system... [És amellett mintha mindegyik érezte volna, hogy most ők jönnek, uralomra jutni (...); nem látszott még ilyen világosan, de volt valami megváltozott a hangjukban, valami biztonság, ami kényelmetlen sejtelmekkel töltött el; jóformán csupa zsidó körülöttem ... Ezek a furcsa, bágyadt, sok tekintetben nagyrészt degenerált külsejủ és másfajta, idegen - százszor idegen emberek - a mi parasztjaink, a mi középosztályunk, a mi egész társadalmi létünk, állami, lelki berendezkedésünk az élettel szemben.] (225-226)

When it came to memories of the other, Lesznai's sparse entries on the Sunday meetings mentioned Ritoók two or three times, in each instance citing her remark or contribution to a philosophical discussion in a tone that remained unfailingly respectful and unemotional. As for Ritoók, I already cited her pointed description of the last 
Szapor, Judith. "Disputed Past: The Friendship and Competing Memories of Anna Lesznai and Emma Ritoók." AHEA: E-journal of the American Hungarian Educators Association, Volume 5 (2012): http://ahea.net/e-journal/volume-5-2012

meeting between her and Lesznai. But that was not her last word on the subject. Ritoók kept returning to Lesznai, clearly treating the relationship as emblematic of her past and continuing to justify - to herself and her prospective readers - the reasons for her rejection of this shared past.

An entry from the 1920s invoked the memory of Ritoók's earlier stay at Körtvélyes, Lesznai's family estate. (The reference to Lesznai as "still” Mrs. Jászi helps to date the visit to the latter years of the war.) Ritoók enjoyed the Moscovitz family's hospitality for a few weeks, and recalled fondly the idyllic environment, Lesznai's gracious and hospitable mother, the writer's intelligent views on "womanly issues," the masses of books, and the intellectual level of conversation. She also complimented Máli (Lesznai's nickname) on "her multiple talents," her ability to assimilate to the Hungarian spirit, and her genuine understanding of folklore, reflected in her emborideries. Lesznai's love of the soil and of nature, added Ritoók, also likened her to Hungarian women as the Moscovitz household resembled that of the Hungarian gentry. Ritoók even noted that the area's Hungarian landowners treated the family as one of their own and also remarked that Lesznai's appearance did not strike one as Jewish. Yet there were ominous signs of Lesznai's difference, continued Ritoók: "Her scope of culture was entirely different from that of Hungarian families, strongly foreign, thus her world view was unlike ours. In intimate conversation she revealed herself to be much more erotic than a Hungarian woman and when she was dressing - a Hungarian woman would be much more modest, even in front of another woman." [De a müveltsége teljesen más volt, mint a magyar családoké, erősen külföldi és igy világnézeti gondolkozása sem a miénk. Bizalmas beszélgetésben sokkal erotikusabbnak mutatkozott, mint magyar nő lett volna és mikor öltözködött - magyar nő még másik nő elött is szemérmesebb.] (173-74). All this is damning praise in which genuine admiration for Lesznai's artistic talents and her family's gentry lifestyle is tempered with the familiar tropes of anti-Semitism: excessive sexuality and the prodigious ability of the Jews to assimilate, only to destroy the host nation from within. Throughout her memoirs, Ritoók returned over and over again to the personal relationships with her old Sunday friends, to reflect on them in light of her new-found anti-Semitic convictions, as if to look for the signs that should have forewarned her.

To this earlier note on her erstwhile friend Ritoók attached a post-script from the 1920s, further developing the theme of Lesznai's sexual and political transgressions :

Anna Lesznai became a Communist and to this day lives at Körtvélyes, under Czech rule. She must be as good a Czech patriot as she was a Hungarian one. Unless she is still a Communist, for, as I hear from an aquaintance there, a gentry woman with whom she used to socialize, she associates with horrible people, from the Viennese exile camp, and she has become a woman of terrible reputation. Of course her Hungarian acquaintances refuse to see her... [Lesznai Anna kommunista lett és ott lakik ma is Körtvélyesen cseh uralom alatt... bizonyosan épen olyan jó cseh hazafi, mint magyar volt. Hacsak nem kommunista ma is, mert egy felvidéki ismerősömtől hallottam, egy dzsentri asszonytól, akivel régen jó ismeretségben volt, hogy szörnyü társaság jár hozzá Bécsböl az 
Szapor, Judith. "Disputed Past: The Friendship and Competing Memories of Anna Lesznai and Emma Ritoók." AHEA: E-journal of the American Hungarian Educators Association, Volume 5 (2012): http://ahea.net/e-journal/volume-5-2012

emigrációs táborból és hogy nagyon rossz hirủ asszony lett belőle. Természetesen magyar ismerősei sohasem találkoznak többé vele...]

In another post-script, dated from the 1930s, Ritoók commented with undisguised malice on Lesznai's reappearance in Budapest:

Still later I must add: how naive of me! ... Anna Lesznai simply returned to Hungary in the 1930s - it seems this poor, backward Hungary is still better than her adored Czech country. And here at home she is a celebrated artist - when she is a far worse artist than poet - who exhibits and is embraced by aristocratic ladies as a magical talent. [Kénytelen vagyok még később kiegesziteni: milyen naiv voltam megint! ... Lesznai Anna egyszerüen visszajött a 30-as években Magyarországba - úgy látszik ez az állandóan lenézett Magyarország mégis jobb, mint az imadott Csehország. - Itthon pedig nálunk azóta ünnepelt festőnő - sokkal rosszabb, mint költőnek - kiállit és arisztokrata hölgyek ölelgetik mint tehetség-csodát.] (175)

\section{The afterlife of Ritoók and Lesznai}

In conclusion, we should take a quick glance at the reception and legacy of the two writers after 1945 and after 1989. Lesznai's oeuvre has never become a part of the Hungarian literary canon. But by force of her multiple associations with the early twentieth century's progressive literary and artistic movements - with Ady, the Nyugat, the Sunday Circle, the Eight - her place in the Hungarian fin de siècle was established by the 1970s. As for the merits of her contributions, they were highlighted in a short biography by Erzsébet Vezér (1979) and a volume on the Sunday Circle by Éva Karádi and Vezér (1980). At the same time, Ritoók might have been mentioned as a member of the Sunday Circle occasionally but until 1989 her anti-Semitic views made her literary output anathema. This was especially the case of her novel, A szellem kalandorai. Published in 1921, the novel reflected her attempts to come to terms with her past in light of her newly-held anti-Semitic convictions. A tedious and tendentious read, Ritoók's novel was fixated on the noxious role she attributed to Jews - including most of the Sunday members - in corrupting, from within, Hungary's literary and intellectual life. Likely as a reaction to its previous suppression, Ritoók's oeuvre experienced a small revival after 1989. Her novel A szellem kalandorai was re-issued in 1993, although it failed to reach a success comparable to the works of a Tormay or Wass.

Lesznai's novel, Kezdetben volt a kert was published in a limited run during her visit to Hungary, shortly before her death in 1966. It received no reviews at the time and has remained virtually unknown to general readers and appreciated only by the small circle of specialists of the Hungarian fin de siècle. Lately, however, Lesznai's oeuvre has also experienced a minor revival. Young scholars, especially Petra Török and Csilla Markója, championed her cause both as a writer and artist. Török edited a generous selection of her diaries, published in a stylish, illustrated edition (Török 2010) and she guest-edited a collection of essays on Lesznai in a special, two-volume issue of Enigma (Török 2007). These young scholars consider the novel a masterpiece and argue that it 

Ritoók." AHEA: E-journal of the American Hungarian Educators Association, Volume 5 (2012): http://ahea.net/e-journal/volume-5-2012

should be valued equally for its historical sweep as a family saga, the psychological depth of her characters, and as a documentary source of the early-twentieth-century progressive scene it depicts.

It is no small irony that during the hundred years that followed the two writers' first meeting, neither of them has even approximated the exalted standing that Tormay, a writer and intellectual of much lesser merit, has achieved twice, first in the 1920s and then again, today, both times as a result of a right-wing revival. These developments also serve as a reminder of the obligation of historians and literary scholars to engage with the Hungarian culture wars today and shape a new, post-Communist consensus over the literary canon and historical legacies. Until then, historical and literary legacies will continue to be considered a matter of taste or political leaning and will be decided by bestseller lists, political lobbies, and electoral politics.

\section{Works Cited}

“A Magyartanárok Egyesületének állásfoglalása a „,nemzeti konzervatív” irodalom képviselőnek a Nemzeti alaptantervbe való bekerüléséröl" [The platform of the Association of Hungarian Language and Literature Teachers on the inclusion of representatives of the "national conservative" literature in the National Curriculum]. http://www.magyartanarok.freeweb.hu/frames.html, accessed on 13 August 2012.

Bauer, Tamás. 2012. "Horthy az országgyülésben” [Horthy in Parliament]. Népszabadság online, 4 June 2012. http://nol.hu/lap/forum/20120604horthy_az_orszaggyulesben, accessed on 8 August 2012.

Bihari, Péter. 2008. Löveszárkok a hátországban [Trenches at the Homefront]. Budapest: Napvilág.

Bojtár, Endre. 2012. “Antiszemita vagy-e?” [Are you an Anti-Semite?] Élet és irodalom, LVI/30 (27 July 2012), http://www.es.hu/bojtar_endre;antiszemita_vagy-e;201207-25.html, accessed on 6 August 2012.

Gerő, András. “Akadémikus antiszemitizmus?" [Academic anti-Semitism?] Galamuscsoport (June 30, 2012).

http://galamus.hu/index.php?option=com_content\&view=article\&id=147459:aka demikus-antiszemitizmus\&catid=9:vendegek\&Itemid=66, accessed on 18 August 2012.

Gluck, Mary. 1985. Georg Lukacs and His Generation 1900-1918. Cambridge, Mass.: Harvard University Press.

Jászi, Oszkár. 1955. "Emlékiratok” [Memoirs]. Eds. Litván, György and János F. Varga. Jászi Oszkár publicisztikája [The Writings of Oszkár Jászi]. Budapest: Magvető.

Kádár, Judit. 2009. “A Fasiszta biznisz felvirágzása - Tormay Cécile Bujdosó könyvének legfrissebb kiadásáról" [The Blossoming of Fascist Business - on the Newest Edition of Cécile Tormay's Diary of an Outlaw]. Magyar Narancs vol. 30 (23 July 2009), http://magyarnarancs.hu/konyv/a_fasiszta_biznisz_felviragzasa__tormay_cecile_bujdoso_konyvenek_legfrissebb_kiadasarol-71834, accessed on 13 December 2011. 
Szapor, Judith. "Disputed Past: The Friendship and Competing Memories of Anna Lesznai and Emma Ritoók." AHEA: E-journal of the American Hungarian Educators Association, Volume 5 (2012):

http://ahea.net/e-journal/volume-5-2012

Karádi, Éva and Vezér Erzsébet. 1980. A Vasárnapi Kör; Dokumentumok [The Sunday Circle; Documents]. Budapest: Gondolat.

Károlyi, Mihályné. 1967. Együtt a forradalomban [Together in the Revolution]. Budapest: Európa.

Kollarits, Krisztina. 2010. Egy bujdosó irónö - Tormay Cécile [An Outlaw Writer Cécile Tormay]. Vasszilvány: Magyar Nyugat Kiadó.

Lengyel András. 1994. "A Vasárnapi Kör 'renegátja." Utak és csapdák; Irodalom- és müvelödéstörténeti tanulmányok [The Renegade of the Sunday Circle. Paths and Traps; Studies in Literary and Cultural History]. Budapest: Tekintet 1994, 7-76.

Lesznai, Anna. 1966. Kezdetben volt a kert [In the Beginning was the Garden]. Vols. 1-2, Budapest: Szépirodalmi.

Magyar Közlöny, 2012/60 (4 June 2012), 10635-10847.

Markója, Csilla 2007. "Három kulcsregény és három sorsába zárt "vasárnapos" Lesznai Anna, Ritoók Emma és Kaffka Margit találkozása a válaszúton" [Three Romans-à-clef and Three Sunday Members, Encapsulated in Fate - the Encounter of Anna Lesznai, Emma Ritoók and Margit Kaffka at the Crossroads]. Enigma 52 (2007), 67-108.

Pók, Attila. “Ez lenne a mi „történészvitánk”? [Would this be our Historians’ Debate?] Népszabadság online, 2012. július 31. http://nol.hu/velemeny/20120731ez_lenne_a_mi_torteneszvitank, accessed on 4 August 2012.

Ritoók, Emma. 1903. Egyenes úton egyedül [On a Straight Path, Alone]. Budapest: Singer and Wolfner.

Ritoók, Emma. 1907. A nagy véletlen [The Great Coincidence]. Budapest: Singer and Wolfner.

Ritoók, Emma. 1920-1933. Évek és emberek. [Years and People.] Manuscript, National Széchényi Library, Manuscript Division, fond 473.

Ritoók, Emma. 1921. A szellem kalandorai [The Adventurers of the Spirit]. Budapest:

Romsics, Ignác, ed. 2009. A Magyar jobboldali hagyomány, 1900-1948 [The Hungarian Right-Wing Tradition, 1900-1948]. Budapest: Osiris.

Romsics, Ignác. 2012. “Antiszemita vagyok-e?” [Am I and Anti-Semite?] Élet és Irodalom. LVI. évfolyam, 31. szám, 2012. augusztus 3.

Rubicon, July 2012, http://www.rubicon.hu/magyar/oldalak/antiszemitizmus/.

Szekfü, Gyula. 1920. Három nemzedék; egy hanyatló kor története [Three Generations; History of a Declining Era]. Budapest: Élet.

Szabó, Dezső. 1919. Az elsodort falu [Swept-Away Village]. Budapest: Táltos.

Török, Petra. 2007. “...Csak szeglet, fény és töredék. Mint ez a napló;” Lesznai Anna naplójegyzeteiröl" [... Only Angle, Light and Fragment. Just as this Diary; On the Diaries of Anna Lesznai"]. Enigma, vol. XIV, no. 51 (2007: 46-63).

Török, Petra, ed. 2010. Sorsával tetováltan önmaga; Válogatás Lesznai Anna naplójegyzeteiböl [Tattoed by Her Fate, Herself; Selections from the Diaries of Anna Lesznai]. Budapest: Petőfi Irodalmi Múzeum és Hatvany Lajos Múzeum.

Keno Verseck, "Hungary Rehabilitates Far-Right Figures," Spiegel Online, 6 June 2012 http://www.spiegel.de/international/europe/right-wing-extremists-cultivate-horthy-cultin-hungary-a-836526-druck.html 
Szapor, Judith. "Disputed Past: The Friendship and Competing Memories of Anna Lesznai and Emma Ritoók." AHEA: E-journal of the American Hungarian Educators Association, Volume 5 (2012):

http://ahea.net/e-journal/volume-5-2012

Vezér, Erzsébet. 1979. Lesznai Anna élete [The Life of Anna Lesznai]. Budapest: Kossuth. 